Jpn. J. Human Genet. 31, 45-48, 1986

\title{
DE NOVO PARTIAL MONOSOMY 21 WITH UNUSUAL KARYOTYPE
}

\author{
S.A. Al-Awadi, K.K. Naguib, A.S. Teebi, \\ and T.S. SUNDARESHAN \\ Kuwait Medical Genetics Centre, P.O. Box 4080, Safat-Kuwait
}

\begin{abstract}
Summary A fifteen month old girl with multiple congenital anomalies, mental retardation and de novo partial monosomy 21 with unusual karyotype is described. Anomalies are hypertonia, scaphocephaly, prominent occiput, hypertelorism, telecanthus, antimongoloid slanting of the eyes, absent philtrum pillars, characteristic long tapering spindie shaped fingers with adducted thumbs crossing the palm. High resolution banding showed mosaic two cell lines each with a modal number of 45 chromosomes, but carrying different translocations finally resulting in partial monosomy for the segment $21 \mathrm{pter} \rightarrow \mathrm{q} 21.2$.
\end{abstract}

\section{INTRODUCTION}

Most cases of partial monosomy 21 reported so far are due to malsegregation of the parental translocation and in rare instances it occurs de novo with the loss of centromere (Grouchy and Turleau, 1984). Here we present a case with de novo partial monosomy 21 with unusual karyotype having two cell lines each with 45 chromosomes carrying different translocations and resulting in partial monosomy 21 where the exact limits of monosomy is confirmed by high resolution G-banding.

\section{CASE REPORT}

The proposita (R.A.S) was the product of the second full term pregnancy to a 24-year-old mother and 37-year-old father who are first cousins once removed. The pregnancy was complicated early in the first trimester by sinusitis, thyroid problems and polyhydramions. Unaware of pregnancy mother had repeated exposures to $X$ rays (6-7 times). Proband's birth weight was $1.9 \mathrm{~kg}$ and length was $43 \mathrm{~cm}$, both were below the third centile for age but head circumference was $34 \mathrm{~cm}$ which is at 50th centile.

Received September 13, 1985 


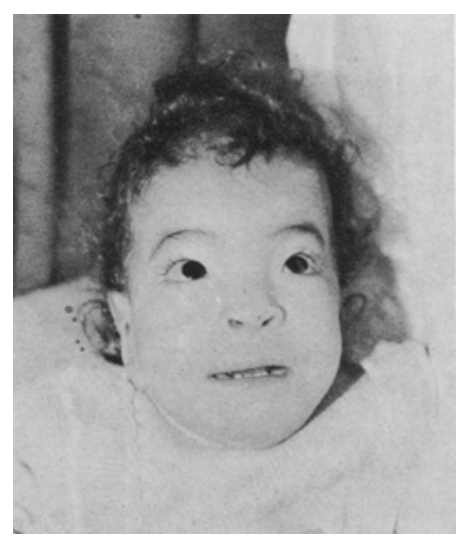

Fig. 1. The proposita.

Examination at the age of one month showed: prominent forehead, prominent occiput, scaphocephaly, epicanthic folds, antimongoloid slants, telecanthus, apparent hypertelorism, squint, prominent glabellae, broad nasal bridge, high arched cleft palate, normally set ears with prominent antihelix and small chin. She also had widely spaced nipples, umbilical hernia, long tapering spindle shaped fingers with bilateral clinodactyly of the 4th and 5 th fingers together with long tapering toes. Thumbs were adducted and crossing the palm bilaterally with hypoplastic dermal ridges. Sacrococygeal dimple and generalized hypertonia were also noted. On examination at the age of 15 month she showed all abnormalities noted earlier together with growth retardation, severe developmental retardation, narrow pelvis and congenital heart disease (Fig. 1). The hand and feet length were $7.3 \mathrm{~cm}$ and 8.3 $\mathrm{cm}$, respectively $(<3$ rd centile).

Biochemical routine investigations showed no abnormality. Skeletal radiographs did not reveal any significant changes.

\section{CYTOGENETICS}

Chromosomal analysis performed on lymphocytes of the proposita using trypsin-G, Q, R and $C$ bandings revealed two distinct cell lines both with a modal number of 45 chromosomes with only one normal 21 . One cell line showed $11 \mathrm{p}+$ and the other $20 \mathrm{q}+$ with all other chromosomes having normal morphology. The two cell lines were in the ratio of $60: 40$, respectively. The extra part on these chromosomes was identified clearly by high resolution G-banding using ethidium bromide pretreatment technique of Ikeuchi (1984) to be distal portion of $21 \mathrm{q}$ ( $21 \mathrm{q} 21.3 \rightarrow$ qter). The karyotype was interpreted as $\operatorname{mos} 45, \mathrm{XX},-21, \mathrm{t}(11 ; 21)(11 \mathrm{qter} \rightarrow 11 \mathrm{p} 15.3:$ : $21 \mathrm{q} 21.3 \rightarrow 21 \mathrm{qter}) / 45, \mathrm{XX},-21, \mathrm{t}(20 ; 21)(20 \mathrm{pter} \rightarrow 20 \mathrm{q} 13.3:: 21 \mathrm{q} 21.3 \rightarrow 21 \mathrm{qter})$ (Fig. 2). Parental chromosomes were normal. 

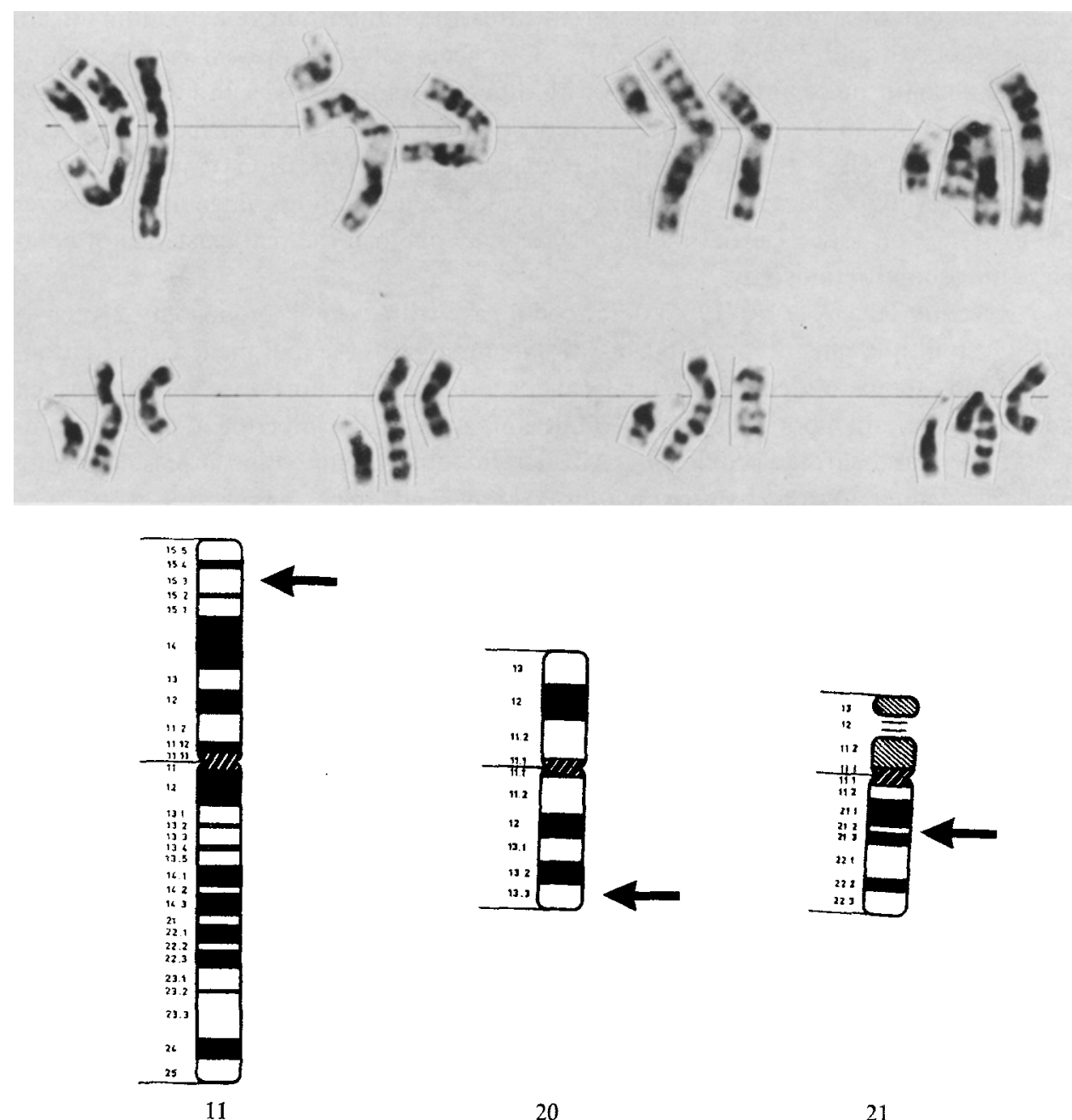

Fig. 2. High resolution trypsin-Giemsa banded partial karyotype showing chromosomes in triplets. Top line represents $11 p+$ cell line. Abnormal 11 is placed in the centre and the normal homologue is to the extreme right of each triplet. Middle line represents $20 \mathrm{q}+$ cell line. Abnormal 20 is placed in the centre and the normal homologue is to the extreme right of each triplet. Normal 21 is to the extreme left of each triplet and is placed in such a way as to correspond with the extra bands on the abnormal chromosomes. Bottom line shows the schematic representation of normal chromosomes with arrows indicating the break points.

\section{DISCUSSION}

The advances of the recent banding techniques has made the diagnosis of structural chromosomal abberations more precisely. Since the early description of antimongolism by Lejeune et al. (1964), 23 cases with partial monosomy 21 have been 
described out of which 19 were reported after the establishment of banding techniques (Nielsen and Tranebjaerg, 1984). Cytogenetically the present case is unique with 45 chromosomes in two cell lines with different translocations and final outcome being the same in both. Complete monosomy 21 has been described by several authors nevertheless the question of undetectable translocation is raised. It is worth reviewing such cases utilizing high resolution banding which may uncover the existence of only a partial monosomy or may confirm the real existance of complete autosomal monosomy.

Recently Rivera et al. (1983) described a case with "pure" monosomy 21 pter $\rightarrow$ q21 and multiple phenotypic abnormalities including growth and mental retardation, hypertonia, temperal depression, bilateral epicanthic folds, short nose with antiverted nostrils, long and poorly delineated philtrum, proximally implated thumbs, drumstick fingers and cardiac problems. All such features are noted in our case allowing probable delineation of $21 \mathrm{q}$ proximal monosomy syndrome.

Among all the phenotypic abnormalities spindle shaped tapering fingers, muscular hypertonia, thumb crossing the palm and absent philtrum pillars are characteristic for this monosomy syndrome, which are not usually encountered in other deletion syndromes. Our case has a non-reciprocal de novo translocation which might have occurred during early stages of zygotic division causing partial monosomy 21 and additional monosomies for the terminal portions of $11 \mathrm{p}$ and $20 \mathrm{q}$. The phenotypic consequences of these additional deletions have been masked or modified by the effect of larger monosomy of the segment 21 pter $\rightarrow q 21.2$. It is possible that mother's repeated exposures to $X$ rays during the early weeks of pregnancy might be a cause for these multiple breakages.

Acknowledgements Authors wish to thank Mr. Sulaiman A. Al-Othman, Miss. Sawsan Abul-Hassan, Altaf Ramadan and. Amira Redha for their excellent assistance.

\section{REFERENCES}

Grouchy, J. de and Turleau, C. 1984. Clinical Atlas of Human Chromosomes, II Ed., John Wiley and Sons, New York, pp. 356-359.

Ikeuchi, T. 1984. Inhibitory effect of ethidium bromide on mitotic chromosome condensation and its application to high-resolution chromosome banding. Cytogenet. Cell Genet. 38: 56-61.

Lejeune, J., Berger, R., Rethore, M.O. et al. 1964. Monosomie partielle pour un petit acrocentrique. CR Acad Sci(D) (Paris) 259: 4187-4189.

Nielsen, F. and Tranebjaerg, L. 1984. A case of partial monosomy 21q22.2 associated with Rieger's syndrome. J. Med. Genet. 21: 218-221.

Rivera, H., Rivas, F., Placencia, L., and Cantu, J.M. 1983. "Pure" monosomy 21 pter $\rightarrow q 21$ in a girl born to a couple $46, \mathrm{XX}, \mathrm{t}(14 ; 21)(\mathrm{p} 12 ; \mathrm{q} 22)$ and $46, \mathrm{XY}, \mathrm{t}(5 ; 18)(\mathrm{q} 32 ; \mathrm{q} 22)$. Ann. Genet. 26: 234-237. 